UDK 582.282.16:712.2(1-751.2) (497.6 Sutjeska)

\title{
SOME PEZIZOMYCETES COLLECTED ON THE TERRITORY OF THE SUTJESKA NATIONAL PARK
}

Neki pripadnici razreda Pezizomycetes prikupljeni na području Nacionalnog parka Sutjeska

Nihad Omerbegović ${ }^{1}$, Nedim Jukić ${ }^{1}$

\begin{abstract}
In August 2014, a short mycological research was carried out in the Sutjeska National Park, Bosnia and Herzegovina, at several localities along the rivers Sutjeska and Hrčavka. The main objective of this research was to start documenting presence of fungal species in this area so that a provisional list of potentially rare and endangered species could be proposed in the future. Over 20 species, members of the phylum Ascomycota, were collected and examined (families Pyronemataceae, Pezizaceae, Ascobolaceae and Helotiaceae), some of which were recorded for the first time for Bosnia and Herzegovina. As a first step towards the aforementioned goal, three identified species - Peziza polarispinosa J. MORAVEC, Parascutellinia carneosanguinea (FUCKEL) T. SCHUMACH., Marcelleina brevicostatispora J. MORAVEC were selected to be presented in this paper.
\end{abstract}

Key words: Peziza polarispinosa, Parascutellinia carneosanguinea, Marcelleina brevicostatispora, Pyronemataceae, NP Sutjeska, Tjentište

\section{INTRODUCTION - Uvod}

The mycological research conducted in August 2014 in the Sutjeska National Park was a part of the CfE's ${ }^{2}$ campaign „Bitka za Sutjesku“ that was aimed to provide evidence against construction of small hydroelectric power plants within the territory of the National Park, by collecting biodiversity and ecological data and evaluating potential impact from the announced construction.

The main objective of the mycological research was to produce a list of currently present fungal species, to discover potentially rare and endangered species within protected area and to assess the environmental impact from the habitat alterations.

Since the fungal data for this area are deficient and the species checklist does not exist, the results of this research can be considered as a starting point for the

\footnotetext{
${ }^{1}$ Center for Environment, Banja Luka
} 
prospective systematic inventory of fungi in this protected area and represent significant contribution to the mycology of Bosnia and Herzegovina in general. Results are compared and combined with available official data (USČUPLIĆ 2012).

This research was carried out at several selected localities at riverbanks of Sutjeska and its confluent Hrčavka. The samples were collected and the ecological data were recorded. Three species are selected and documented in detail in this paper: Peziza polarispinosa J. MORAVEC, Parascutellinia carneosanguinea (FUCKEL) T. SCHUMACH., Marcelleina brevicostatispora J. MORAVEC.

Considering the environmental conditions, size and the area status protection, the results of this research indicate high level of fungal diversity. However, it should be noted that the results are obtained in time-limited research. In order to obtain more relevant data, further mycological exploration has to be undertaken.

Table 1. A list of localities where mycological research have been conducted with dates, geographic coordinates and elevation (projection in WGS 84, format Decimal Degrees).

Tabela 1.Lista lokaliteta na kojima su provedena mikološka istraživanja sa datumima, geografskim koordinatama $i$ nadmorskom visinom (projekcija u WGS 84 sistemu, format pozicije decimalni stepen).

\begin{tabular}{|c|l|c|c|c|c|}
\hline No. & \multicolumn{1}{|c|}{ Location } & Date & X & Y & Elevation \\
\hline 1. & $\begin{array}{l}\text { Sutjeska (near camp } \\
\text { Tjentište) }\end{array}$ & 14.08 .2014 & $18.68979 \mathrm{E}$ & $43.35393 \mathrm{~N}$ & $572 \mathrm{~m}$ \\
\hline $\mathbf{2 .}$ & $\begin{array}{l}\text { Hrčavka, Radilište (under } \\
\text { the bridge) }\end{array}$ & 31.08 .2014 & $18.63785 \mathrm{E}$ & $43.35081 \mathrm{~N}$ & $886 \mathrm{~m}$ \\
\hline & $\begin{array}{l}\text { Mouth of Perućica (right } \\
\text { tributary of the Sutjeska } \\
\text { river) }\end{array}$ & 31.08 .2014 & $18.68421 \mathrm{E}$ & $43.32695 \mathrm{~N}$ & $578 \mathrm{~m}$ \\
\hline
\end{tabular}

All three sampling localities represent alpine riverbanks habitats with a lot of plant remnants. Concerning dendroflora, predominance of the Salix (S. alba, S. caprea, S. eleagnos) and Alnus (A. glutinosa) communities has been registered. 


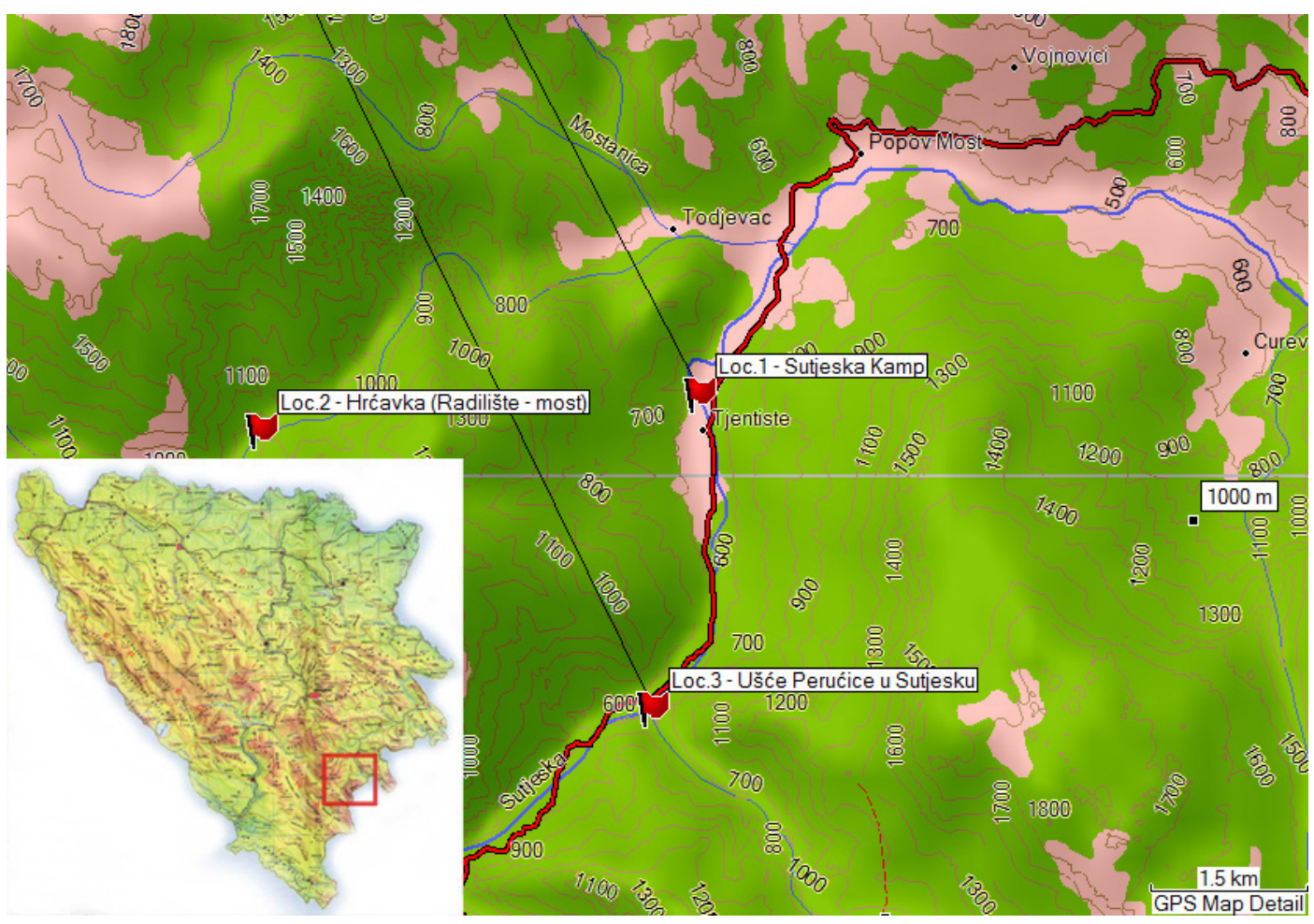

Figure 1. Localities within the territory of NP „Sutjeska“ where mycological research was conducted.

Slika 1. Lokaliteti na teritoriju NP ,,Sutjeska“ u okviru kojih je provedeno mikološko istraživanje.

\section{MATERIAL AND RESEARCH METHODS - Materijal i metode istraživanja}

All registered species were photographed in situ. The specimens were collected and preserved in plastic boxes together with the substrate, as necessary for further treatment and application of vital taxonomy methods (BARAL 1992). Basic morphological characteristics and ecological parameters were registered on site.

The species collections were subsequently microscopically analysed on compound light microscope. Immersion oil lens with the magnification 1000x was used.

Collections were first analysed in tap water in order to observe their vital characteristics (different measurements, spores and paraphyses content). Further analyses were performed using the following chemical reagents: IKI - Lugol's solution (amyloidity), CB - Cotton blue (ornamentation staining), CR - Congo red (observing the excipulum structure, ascogenous tissue, etc). 
Ascospores were measured without polar and lateral ornamentation, using customised software Piximètre ${ }^{3}$.

All specimens were properly preserved by drying (exsiccata) and adequately stored in private herbariums (N.J. - Nedim Jukić, N.O. - Nihad Omerović) and data registered in Amateur mycological association electronic database (FAMU). All the specimens were labeled and assigned unique codes so as the other information necessary for the adequate usage in the GIS system.

\section{RESULTS AND DISCUSSION - Rezultati i diskusija}

After field research and laboratory analysis, a number of species from the phylum Ascomycota were determined, mainly members of the families Pyronemataceae, Pezizaceae, Ascobolaceae and Helotiaceae. Beside the species presented in this paper (Peziza polarispinosa J. MORAVEC, Parascutellinia carneosanguinea (FUCKEL) T. SCHUMACH. and Marcelleina brevicostatispora J. MORAVEC), the following records are also worth mentioning: Miladina lecithina (COOKE) Svrček from a soaked beech log on the riverbank of Perućica stream (near the confluence with river Sutjeska), Peziza gerardii COOKE from the sandy riverbank of Sutjeska and Peziza limnaea MAAS GEEST. from the similar habitats. The genus Scutellinia was presented with five different taxa from several localities on Sutjeska and Hrčavka rivers and Pulvinula convexella (P. KARST.) PFISTER was observed in a number of colonies.

Peziza polarispinosa J. MORAVEC, Agarica 6(12): 59 (1985)

Locality: Sutjeska, camp Tjentište - 14 August 2014

Exsiccata: N.J./140814-07, N.O./140814-06 (duplex)

\section{Description and ecology}

Apothecia 0,5-1,3 cm in diam., first cup shaped, less convexed later. Hymenium surface olive brown, slightly darker towards the centre. Margin is conspicuous; excipulum is darker, brownish, with small granules almost all over the surface.

Outer excipulum (ectal excipulum) is composed of subglobose or globose cells, 14,1$35,1 \mu \mathrm{m}$ wide. Medullary excipulum (medulla) is composed of elongated septate cells, $15,9-29,7 \mu \mathrm{m}$ wide. Paraphyses cylindrical, bifurcate, septate, of the same length as the asci or some protruding above asci; enlarged at the apex, up to 4,6-5,8 $\mu \mathrm{m}$. Asci 360-400 × $14 \mu \mathrm{m}$, cylindrical, 8-spored. Ascospores ellipsoid, hyaline. Ascospores from two apothecia of the same collection have been observed and measured in tap water: $24,1-26,4 \times 10,7-13,2 \mu \mathrm{m}(\mathrm{n}=20)$ and 18,9-23,3 x 9,5-12,4 $\mu \mathrm{m}(\mathrm{n}=40)$ and in CB: $20,7-22,2 \times 8,7-9,7 \mu \mathrm{m}(\mathrm{n}=20)$. Ascospores ornamented; ornamentation units isolated, individual warts $0,3-1,6 \mu \mathrm{m}$ thick, with very conspicuous spiny apiculi on

${ }^{3}$ http://ach.log.free.fr/Piximetre/ - 12.05.2015. 
poles up to 10 (12) $\mu \mathrm{m}$ long, multiapiculate and spinulosapiculate type (HÄFFNER 1986).

Habitat: riverbank, on sandy soil, under Salix sp., Alnus sp., and Petasites sp., in small groups.

Peziza polarispinosa from this locality is the first finding of this species for the territory of Bosnia and Herzegovina.

Notes: Ascospores dimensions recorded by other authors - 19-24,5-27,8 x 8-9,5-10 $\mu \mathrm{m}$ (MORAVEC 1985); 22-27 x 9-10,5 $\mu \mathrm{m}$ (GRADDON 1960).

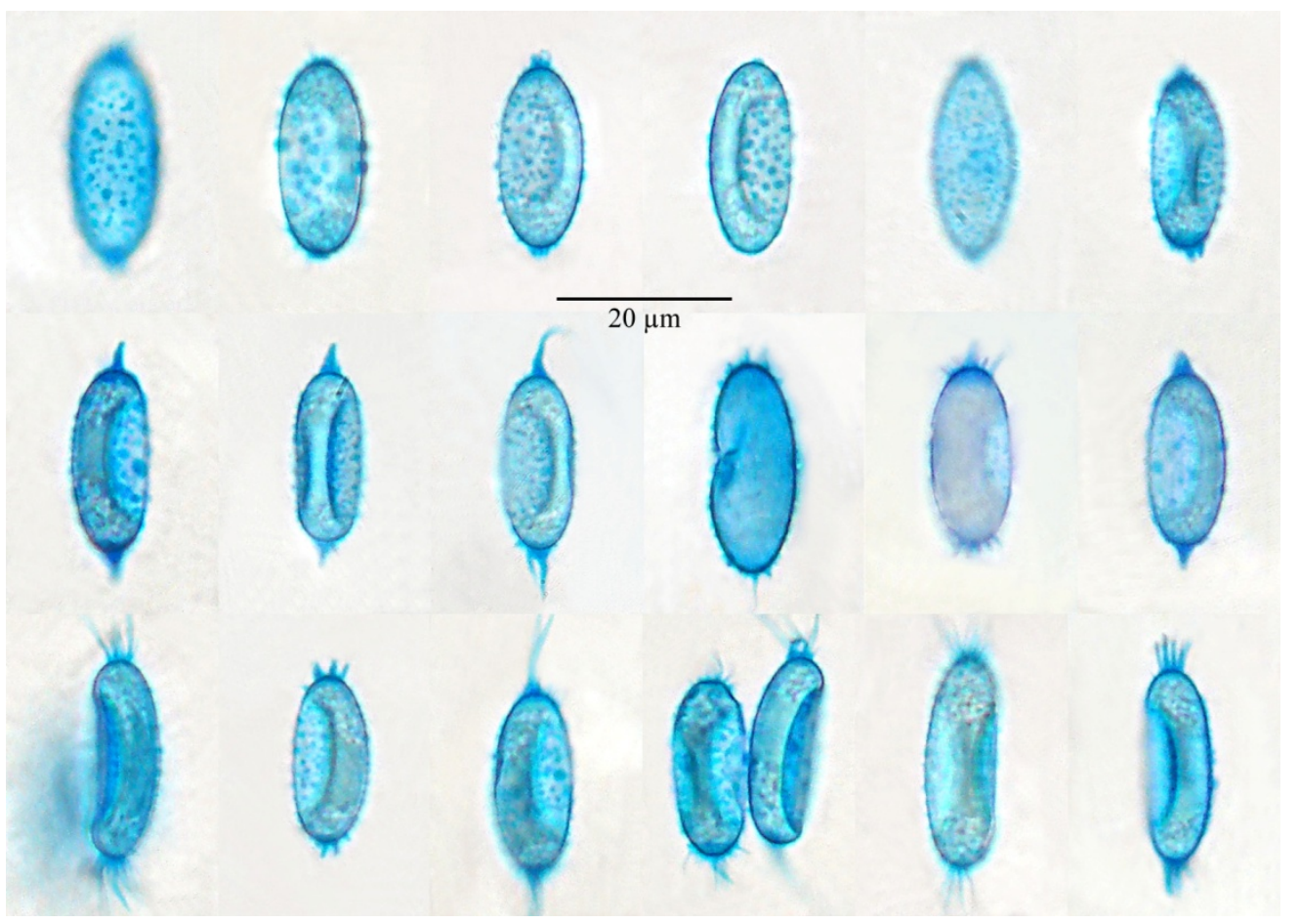

Figure 2. Peziza polarispinosa ascospores in different stages of development treated with Cotton blue. Photo: N. Jukić.

Slika 2. Peziza polarispinosa, askospore različitog stadija razvijenosti bojene pamučno plavim. Foto: N. Jukić. 

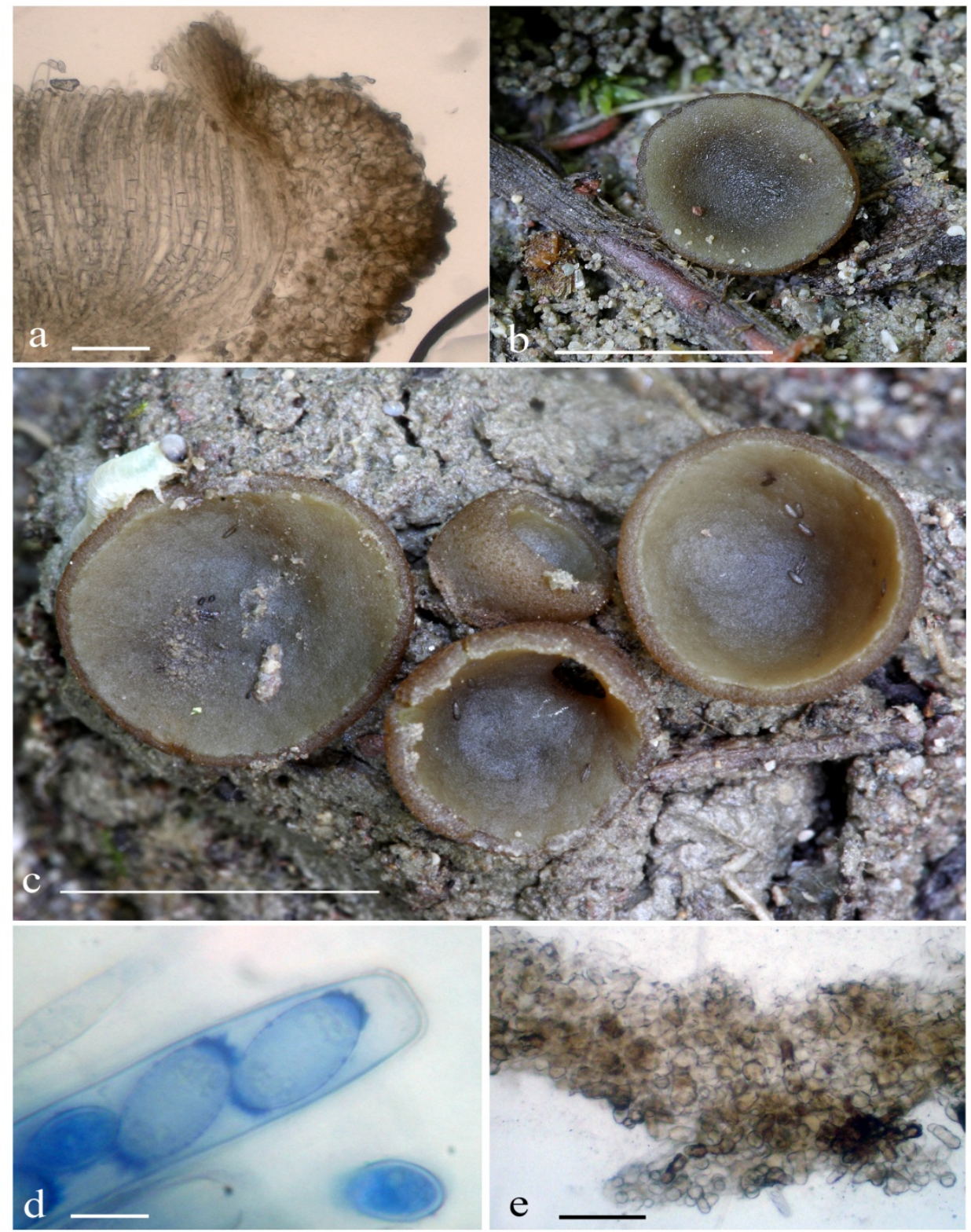

Figure 3. Peziza polarispinosa - a) vertical section of apothecium margin; b) and c) ascomata found on Sutjeska riverbank; d) asci with ascospores and operculum; e) ectal excipulum. Scale bars: $\mathrm{a}=100 \mu \mathrm{m}, \mathrm{b}=10 \mathrm{~mm}, \mathrm{c}=10 \mathrm{~mm}, \mathrm{~d}=10 \mu \mathrm{m}, \mathrm{e}=100 \mu \mathrm{m}$. Photo: $\mathrm{a}, \mathrm{b}, \mathrm{d}, \mathrm{e}-\mathrm{N}$. Omerović; e - N. Jukić.

Slika 3. Peziza polarispinosa - a) marginalni dio apotecija na vertikalnom presjeku; b) i c) plodna tijela pronađena uz obalu rijeke Sutjeske; d) askusi, askospore i operkulum; e) ectal excipulum. Mjerne skale: $\mathrm{a}=100 \mu \mathrm{m}, \mathrm{b}=10 \mathrm{~mm}, \mathrm{c}=10 \mathrm{~mm}, \mathrm{~d}=10 \mu \mathrm{m}, \mathrm{e}=100 \mu \mathrm{m}$. Foto: a,b,d,e - N. Omerović; e - N. Jukić. 
Parascutellinia carneosanguinea (FUCKEL) T. SCHUMACH., Norwegian Journal of Botany 26: 62 (1979)

Basionym: Humaria carneosanguinea FUCKEL, Jahrbücher des Nassauischen Vereins für Naturkunde 23-24: 323 (1870)

Localities: Sutjeska, camp Tjentište - 14 August 2014; Hrčavka (Radilište) - 31 August 2014

Exsiccata: N.J./ 140814-27; N.J./ 310814-07

\section{Description and ecology}

Apothecia cupuliform, less than $1 \mathrm{~cm}$ in diam., usually $0,4-0,8 \mathrm{~cm}$, carmine red, with a tinge of violet. Usually found in small groups or less often as single apothecia.

Parascutellinia carneosanguinea has almost smooth ascospores, ellipsoid and with two large lipid bodies often unequal in size, always with several smaller ones, indistinctly ornamented, finely punctate in Cotton blue, noted also when observing dry specimen, dimensions in tap water 23,9-28,3 x 12,7-15,4 $\mu \mathrm{m}(\mathrm{n}=20)$.

Paraphyses red due to the presence of carotenoid pigments, enlarged at the apex (4-6 $\mu \mathrm{m})$, almost always protrude above the asci; in IKI become olive green.

Marginal hairs and pseudo-hairs usually with simple (unforked) base, with much thinner walls and with less pointed ends in comparison to the hairs of the genus Scutellinia. Hairs up to $750 \mu \mathrm{m}$ in length.

Excipulum is composed of textura globulosa.

Habitat: Parascutellinia carneosanguinea was found on Sutjeska and Hrčavka riverbanks in several small groups on both sites. On all mentioned localities species was found under the mixed willow population (Salix sp.).

Notes:

I - On this site as well as on the previously mentioned sites, presence of Peziza limnaea MAAS GEEST. 1967 was noticed in vicinity of Parascutellinia carneosanguinea, possibly sharing same fruiting conditions.

II - Only previous record of this species in Bosnia and Herzegovina is from the banks of Tušilački creek (25 August 2011, mountain Visočica, near Sarajevo, unpublished data).

III - Ascospores dimensions recorded by other authors - 24-29,5 x 12,5-14,5 $\mu \mathrm{m}$ (DONADINI 1986).

IV - Genus Parascutellinia was described by SVRČEK (1975). Parascutellinia arctespora (COOKE \& W. PHILLIPS) T. SCHUMACH. is correct name to utilize by SCHUMACHER (1988). 


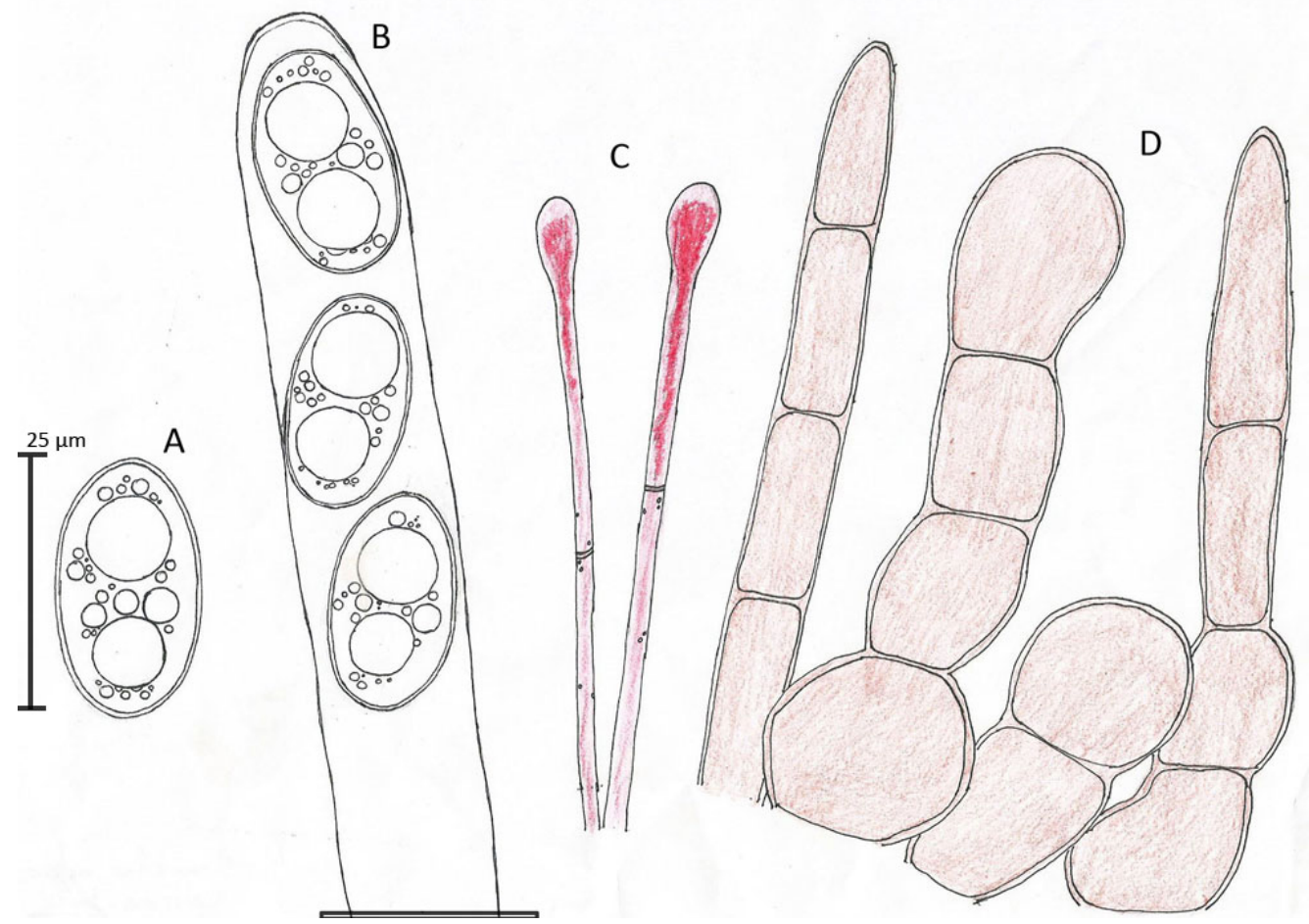

Figure 4. Parascutellinia carneosanguinea - A) mature ascospore; B) apical part of ascus with ascospores;

C) paraphyses; D) marginal hairs and pseudo-hairs. Drawing: N. Jukić.

Slika 4. Parascutellinia carneosanguinea - A) zrela askospora; B) vršni dio askusa sa askosporama; C) parafize; D) marginalne dlačice. Crtež: N. Jukić. 

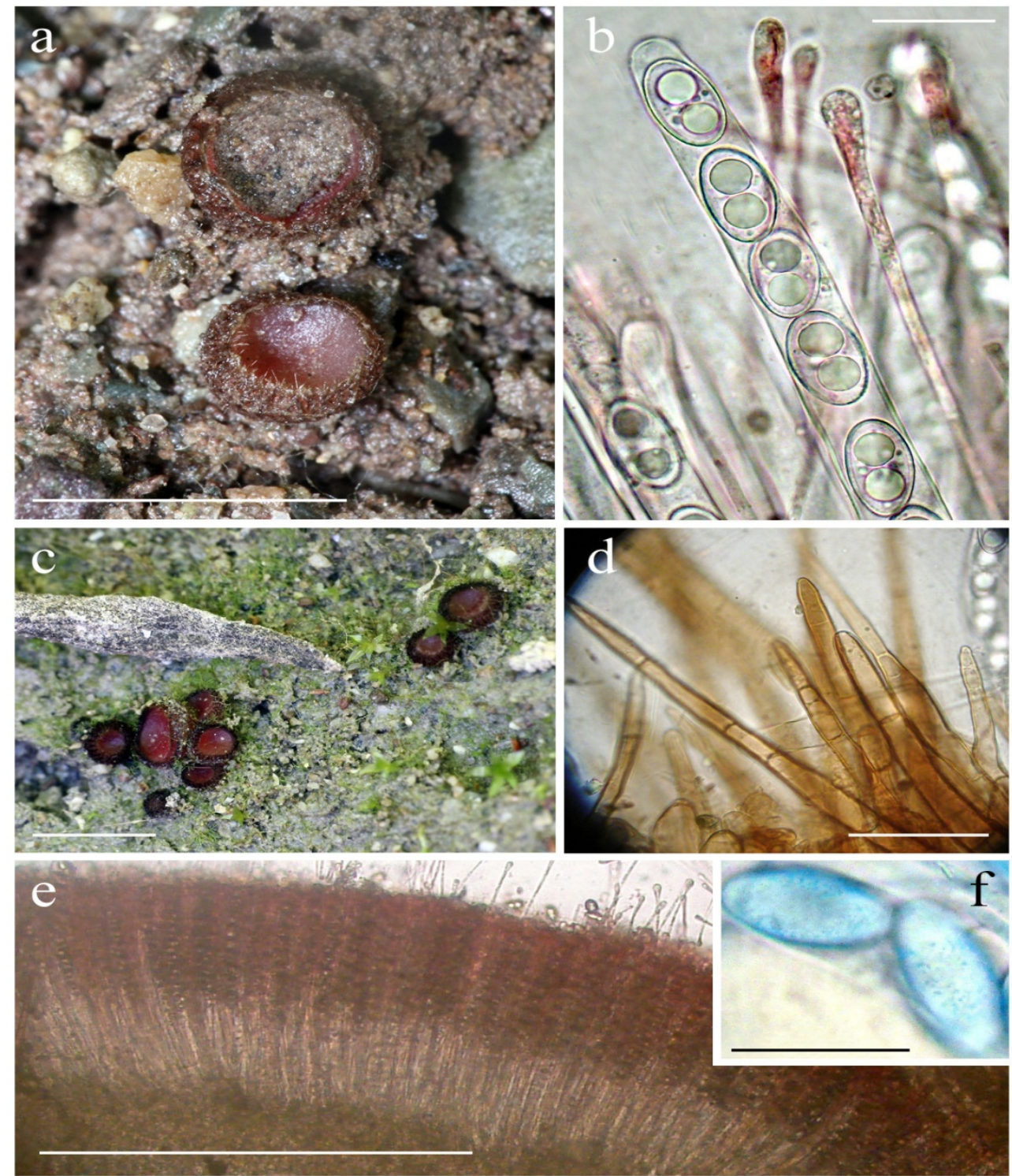

Figure 5. Parascutellinia carneosanguinea - a) and c) groups of ascomata found on Hrčavka and Sutjeska riverbanks;

b) asci, ascospores and paraphyses; d) marginal hairs; e) vertical section; f) ascospores ornamentation in Cotton blue. Scale bars: $\mathrm{a}=1 \mathrm{~cm}, \mathrm{~b}=25 \mu \mathrm{m}, \mathrm{c}=1 \mathrm{~cm}, \mathrm{~d}=50 \mu \mathrm{m}, \mathrm{e}=500$ $\mu \mathrm{m}, \mathrm{f}=20 \mu \mathrm{m}$. Photos: N. Jukić.

Slika 5. Parascutellinia carneosanguinea - a) i c) skupine ascomata pronađene na obalama Hrčavke i Sutjeske; b) askusi, askospore i parafize; d) marginalne dlačice; e) poprečni presjek plodišta; f) ornamentacija askospora posmatranih u pamučno plavom.Mjerne skale: $\mathrm{a}=1 \mathrm{~cm}$, $\mathrm{b}=25 \mu \mathrm{m}, \mathrm{c}=1 \mathrm{~cm}, \mathrm{~d}=50 \mu \mathrm{m}, \mathrm{e}=500 \mu \mathrm{m}, \mathrm{f}=20 \mu \mathrm{m}$. Foto: N. Jukić. 
Marcelleina brevicostatispora J. MORAVEC, Ceská Mykologie 25(4): 198 (1971)

Locality: Sutjeska, camp Tjentište - 14 August 2014

Exsiccata: N.O./ 140814-14

\section{Description and ecology:}

Hymenium dark violet or with the tinge of blue, margin conspicuously darker ${ }^{4}$, surface not completely smooth but slightly granulated.

Asci 8-spored, average dimension $240 \times 16(-17) \mu \mathrm{m}$.

Ascospores globose, 9,5-10,8 $\mu \mathrm{m}$ in diam. (in tap water, $\mathrm{n}=20$ ), with conspicuous and irregular warts and ribs. Ornamentation units isolated, less often barely connected.

Paraphyses septate, straight or sometimes strongly curved in apex, with violet pigment in the upper part; of same length as asci, in apex 3-5 $\mu \mathrm{m}$ wide, not enlarged like those of Marcellina georgii.

Habitat: Marcelleina brevicostatispora was found on Sutjeska riverbank, beneath Petasites $s p^{5}$, upstream from the camp Tjentište (only one apothecium observed and determined).

Notes:

Holotype of $M$. brevicostatispora was originally found and described by Czech mycologist JIŘí MORAVEC in the public park near Ilidža, Sarajevo, beneath Platanus $s p$. (MORAVEC 1971).

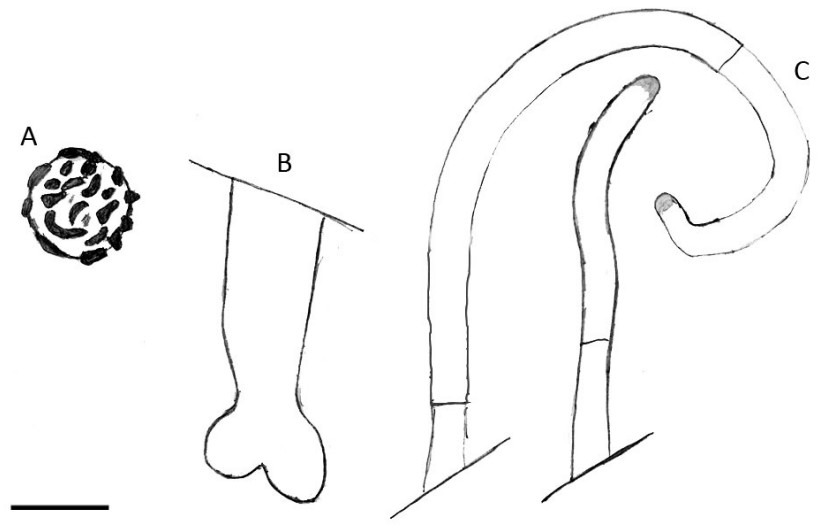

Figure 6. Marcelleina brevicostatispora - A) mature ascospore; B) ascus base; C) paraphyses. Scale bar: $10 \mu \mathrm{m}$ Drawing: N. Omerović.

Slika 6. Marcelleina brevicostatispora - A) zrela askospora; B) baza askusa; C) parafize. Mjerna skala: $10 \mu \mathrm{m}$. Crtež: N. Omerović.

\footnotetext{
${ }^{4}$ MORAVEC (1987) describes margin paler.

${ }^{5}$ MORAVEC (1987) also noted association with Petasites $s p$.
} 

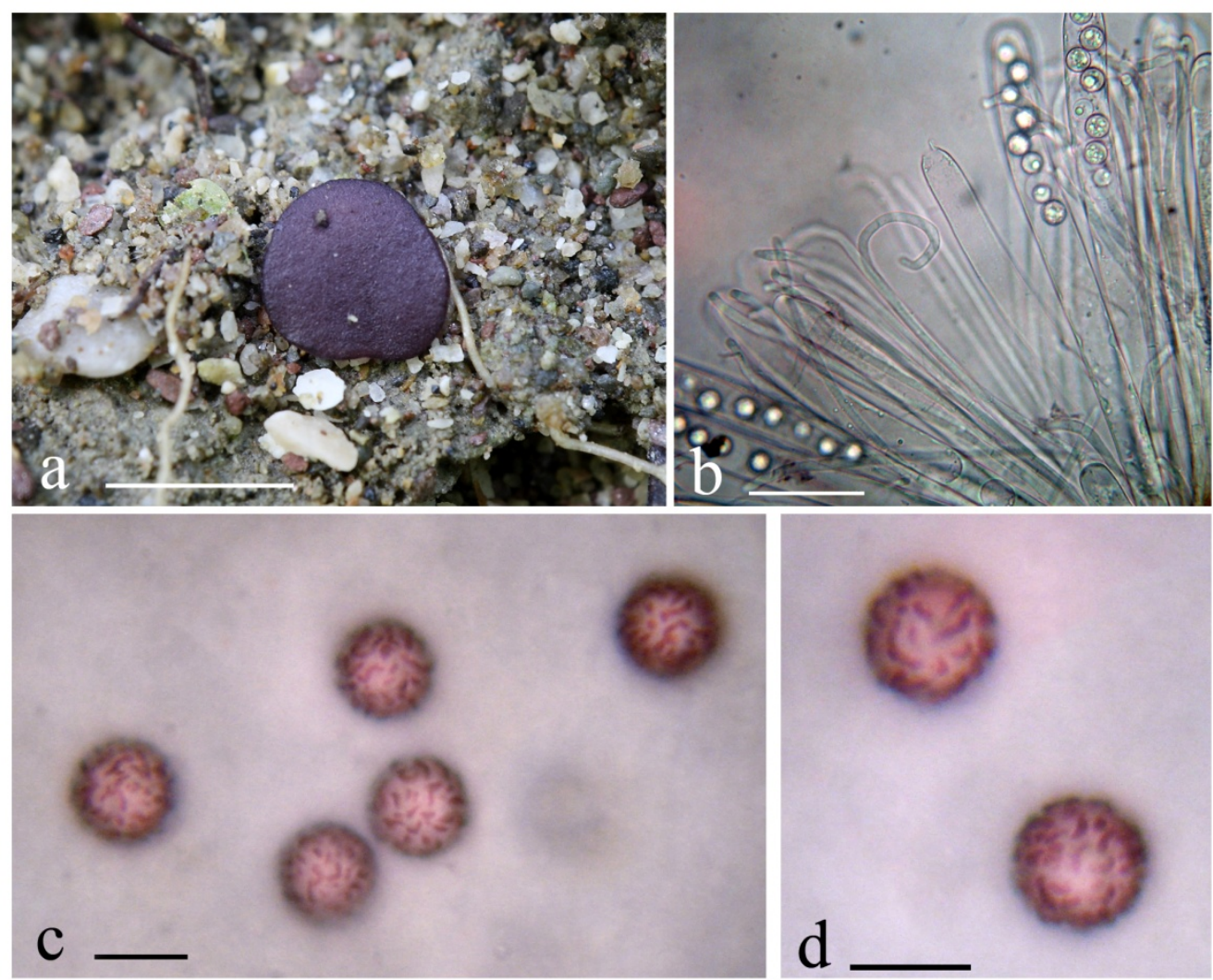

Figure 7. Marcelleina brevicostatispora - a) ascoma in situ, Sutjeska riverbank; b) ascospores, asci and paraphyses; c) and d) ascospores and distinctive ornamentation. Scale bars: $a=5 \mathrm{~mm}$, $\mathrm{b}=50 \mu \mathrm{m}, \mathrm{c}=10 \mu \mathrm{m}, \mathrm{d}=10 \mu \mathrm{m}$. Photo: N. Omerović.

Slika 7. Marcelleina brevicostatispora - a) plodno tijelo na pjeskovitom tlu, obala rijeke Sutjeske; b) askospore, askusi i parafize; c) i d) askospore i karakteristična ornamentacija. Mjerne skale: $\mathrm{a}=5 \mathrm{~mm}, \mathrm{~b}=50 \mu \mathrm{m}, \mathrm{c}=10 \mu \mathrm{m}, \mathrm{d}=10 \mu \mathrm{m}$. Foto: N. Omerović.

\section{CONCLUSIONS - Zaključci}

The mycological research carried out in August 2014 in the Sutjeska National Park resulted in identifying significant number of rare species of the phylum Ascomycota. These results represent very important and valuable contribution to the knowledge on mycobiota of NP Sutjeska and for mycology of Bosnia and Herzegovina in general. These findings support the claim that Hrčavka and Sutjeska riverbanks are some of the most valuable natural habitats in Bosnia and Herzegovina and as such require extensive mycological research in the future. This will provide much better picture of fungal diversity and could result in further measures for protection and conservation of the area and its mycobiota. 
However, Sutjeska National Park is facing serious ecological threat manifested in planned construction of the five small hydroelectric power plants on Hrčavka and Sutjeska rivers as stated in the public study „Hidroenergetska osnova

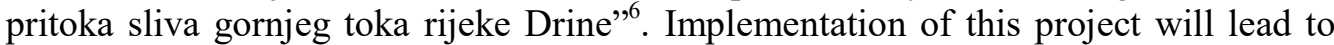
diverting a significant amount of river's flow through pipelines which will result in major changes in water regime (partial or complete drainage of riverbed) causing damaging alterations of the typical riverbank habitats. Such alterations may be especially destructive for the fungal species highly dependent on natural water regime and riparian vegetation that require permanent presence of humidity. Finally, this could lead to the depopulation of some species and even to their local extinction.

\section{REFERENCES - Literatura}

BARAL, H.-O. (1992). Vital versus herbarium taxonomy: morphological differences between living and dead cells of ascomycetes, and their taxonomic implications. Mycotaxon. 44(2): 333-390.

DONADINI, J.C. (1986). Parascutellinia violacea (Vel.) Svrček - nom correct pour Humaria carneo-sanguinea Fuckel - espèce commune dans les Alpes Françaises. Bull. Féd. Myc. Dauphiné-Savoie, 100: 57-62.

GRADDON, W.D. (1960). British records nos. 43-49. Transactions of the British Mycological Society. 43(4): 689-691.

HÄFFNER, J. (1986). Die apiculaten Becherlinge. Zeitschrift für Mykologie, 52: 189212.

MORAVEC, J. (1971). Some operculate Discomycetes from the park in Ilidža near Sarajevo (Jugoslavia). Ceská Mykologie, 25(4): 197-202.

MORAVEC, J. (1985). A taxonomic revision of species related to Peziza apiculata. Agarica, 6(12): 56-66.

MORAVEC, J. (1987). A taxonomic revision of the genus Marcelleina. Mycotaxon, 30: 473-499.

SCHUMACHER, T. (1988). The Scutellinia battle: the lost, missing and dead. Mycotaxon 33: 149-189.

SVRČEK, M. (1975). New or less known Discomycetes. II. Ceská Mykologie, 29(3): 129-131.

USČUPLIĆ, M. (2012). Više gljive - Macromycetes. Akademija nauka i umjetnosti Bosne i Hercegovine, Djela, knjiga LXXXV, odjeljenje prirodnih i matematičkih nauka, knjiga 8. Str. 284.

ERS: http://www.ers.ba/stara/malehe.htm (viewed 10 January 2015).

${ }^{6}$ http://www.ers.ba/stara/malehe.htm (viewed on January 10th 2015.). 


\section{SAŽETAK}

Tokom augusta 2014. godine provedeno je mikološko istraživanje i prikupljanje uzoraka uz obalna područja rijeka Hrčavke i Sutjeske (područje Nacionalnog parka Sutjeska), a s ciljem kontribucije poznavanju diverziteta gljiva Bosne i Hercegovine.

Sve pronađene vrste su fotografisane in situ i uzorkovane radi naknadnih mikroskopskih analiza, a za iste su zabilježene osnovne karakteristike samih staništa. Nakon provođenja svih neophodnih analiza eksikati vrsta su pohranjeni u privatne herbarije.

U okviru pomenutih terenskih istraživanja na teritoriji NP Sutjeska zabilježeno je niz značajnih i izuzetno vrijednih nalaza za mikofloru Bosne i Hercegovine, a u radu su predstavljeni i ukratko opisani neki od pronađenih operkulatnih diskomiceta.

Izdvojene su, opisane, te makroskopski i mikroskopski prezentirane sljedeće vrste: Peziza polarispinosa (prvi put zabilježena na teritoriji Bosne i Hercegovine), Parascutellinia carneosanguinea (do sada poznata sa jednog lokaliteta na prostoru Bosne i Hercegovine), te Marcelleina brevicostatispora (vrsta čiji je holotip pronađen u okolini Sarajeva prije 45 godina).

Diverzitet i ukupan broj pronađenih vrsta na predmetnim područjima ukazuju na značaj i očuvanost staništa u okviru NP Sutjeska koja bi svakako u dogledno vrijeme trebalo detaljnije istražiti.

Ova staništa i pripadajuće vrste su ujedno i potencijalno ugrožene jer je na prirodnim tokovima Hrčavke i Sutjeske, odnosno na teritoriji Nacionalnog parka, planirana izgradnja pet manjih hidrocentrala, te djelomično isušivanje istoimenih rijeka.

Zbog svega navedenog nužno je realizovati dodatna sistematska istraživanja askomiceta ovog područja, te dati jasne preporuke i usmjerenja za dalje korake orijentisane ka očuvanju vrijednih staništa za gljive ovog područja. 